\title{
Parasitism on Araneus venatrix (Koch, 1838) (Araneae: Araneidae) by Hymenoepimecis silvanae Loffredo and Penteado-Dias, 2009 (Ichneumonidae, Pimplinae) with description of male of the wasp
}

\author{
Sobczak, JF. ${ }^{*}$, Loffredo, APS. ${ }^{a}$ and Penteado-Dias, AM. ${ }^{b}$

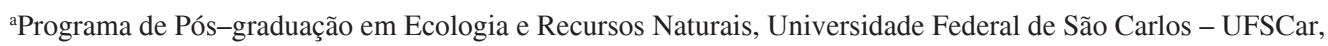 \\ Rod. Washington Luis, Km 235, CEP 13565-905, São Carlos, SP, Brazil \\ bDepartamento de Ecologia e Biologia Evolutiva, Universidade Federal de São Carlos - UFSCar, \\ Rod. Washington Luis, Km 235, CEP 13565-905, São Carlos, SP, Brazil \\ *e-mail: jobczak@gmail.com \\ Received February 9, 2011 - Accepted March 22, 2011 - Distributed February 29, 2012
}

(With 1 figure)

\begin{abstract}
The wasp Hymenoepimecis silvanae Loffredo and Penteado-Dias, 2009, was recorded parasitising females of Araneus venatrix. The male of $H$. silvanae is described and illustrated. Specimens were collected in the Parque Estadual de Intervales and Reserva Biológica Serra do Japi, both located in the state of São Paulo, Brazil.
\end{abstract}

Keywords: Polysphincta, Hymenoepimecis, parasitoid of spider, host.

\section{Parasitismo em Araneus venatrix (Koch, 1838) (Araneae: Araneidae) por Hymenoepimecis silvanae Loffredo and Penteado-Dias, 2009 (Ichneumonidae, Pimplinae), com descrição do macho da vespa}

\begin{abstract}
Resumo
A vespa Hymenoepimecis silvanae Loffredo and Penteado-Dias, 2009 foi registrada parasitando fêmeas de Araneus venatrix. O macho de $H$. silvanae, é descrito e ilustrado. Os espécimes foram coletados no Parque Estadual de Intervales e na Reserva Biológica Serra do Japi, ambos localizados no Estado de São Paulo, Brasil.
\end{abstract}

Palavras-chave: Polysphincta, Hymenoepimecis, parasitoide de aranha, hospedeiro.

\section{Introduction}

Spiders are present in the diet of several predators, and are also attacked by parasites and parasitoids with varying degrees of food specificity (Gonzaga, 2008). Of these, wasps of the subfamily Pimplinae (Hymenoptera, Ichneumonidae) included in Polisphinctine genus-group (Polysphinctini sensu Townes 1969; hereafter "polysphinctines) are exclusively ectoparasitoid koinobiont of spiders (Gauld and Dubois, 2006).

Hymenoepimecis is a large-sized polysphinctine genus distributed from Mexico and Cuba to southern Brazil (Gauld 2000, Gauld and Dubois 2006). The species are characterised by the presence of a pocket-like structure on the pronotum, mesopleuron with carina epicnemial vestigial or absent, absence of the vein $3 \mathrm{rs}-\mathrm{m}$ in fore wing (Gauld, 1991), colour yellowish brown and large ocelli (Gauld and Dubois, 2006). All known species are koinobiont parasitoids of adult spiders of the family Nephilidae, Tetragnathidae and Araneidae (Fincke et al., 1990; Eberhard, 2000; Gauld, 2000; Gonzaga and Sobczak,
2007; Sobczak et al., 2009; Gonzaga et al., 2010). Despite this wide geographical distribution, little is known on host identities. Record of host uses are available for eight species: Hymenoepimecis bicolor (Brulle, 1846) attacks immature females and males of Nephila clavipes (Linnaeus, 1767) (Nephilidae) (Gonzaga et al., 2010); Hymenoepimecis sooretama Sobczak et al., 2009 (Sobczak et al., 2009) entered the three-dimensional structure of the web and attacks Manogea porracea (C.L. Koch, 1838) (Araneidae) (Sobczak et al., 2009); Hymenoepimecis veranii Loffredo and Penteado-Dias, 2009, parasitoid of Araneus omnicolor (Keyserling, 1893) (Araneidae) (Gonzaga and Sobczak 2007, Sobczak et al., 2011); Hymenoepimecis robertsae Gauld 1991, attacks females of N. clavipes in Panamá (Fincke et al., 1990) and Costa Rica (Gonzaga et al., 2010); Hymenoepimecis argyraphaga, Gauld 2000, a parasitoid of Leucauge argyra (Walckenaer, 1842) (Tetragnathidae) in Costa Rica (Eberhard 2000). Hymenoepimecis japi Sobczak et al., 2009 (Sobczak et al., 
2009) changes the behaviour of web building in the spider Leucauge roseosignata Mello-leitão, 1943 (Tetragnathidae). A single individual of Hymenoepimecis heidyae Gauld 1991 in Costa Rica was record in Kapogea sexnotata (Simon 1895) (Araneidae) (Gauld, 2000). The aim of this study was to describe the male of Hymenoepimecis silvanae, and the record of its host Araneus venatrix (Araneidae).

\section{Material and Methods}

Three females of the spider A. venatrix with larva of $H$. silvanae attached to the abdomen were located along the forest border in December of 2009 in the Parque Estadual de Intervales ( $24^{\circ} 16^{\prime} \mathrm{S}$ and $48^{\circ} 25^{\prime} \mathrm{W}$ ), Ribeirão Grande, state of São Paulo, Brazil; and one female of A. venatrix was photographed in the field (Figure 1a), and collected in February of 2010 in Serra do Japi (23 15' S and $46^{\circ} 57^{\prime} \mathrm{W}$ ), an area of subtropical forest located in Jundiai, state of São Paulo, Brazil.

Spiders parasitised from both places were collected, enclosed in plastic recipients $(30 \times 25 \times 25 \mathrm{~cm})$ and fed daily with Drosophila sp. specimens. In the laboratory, the parasitoid specimens that emerged from the cocoons were examined, measured and photographed in a Leica M 205 C stereomicroscope. Voucher specimens of the parasitoid were deposited in the collection of the Universidade Federal de São Carlos - UFSCar, (DCBU- A.M. Penteado-Dias, curator), and the spiders are deposited in the Instituto Butantan, São Paulo (IBSP, A.D. Brescovit, curator).

\section{Results and Discussion}

After 10 days (n: 4) two females and two males of $H$. silvanae emerged from the cocoon. Loffredo and Penteado-Dias (2009) described the female of $H$. silvanae with holotype collected using a Malaise trap in Campos do Jordão, SP, Brasil. The male of $H$. silvanae used in this work emerged from a female of $A$. venatrix is described below:

Male: Length: $10.5 \mathrm{~mm}$. Fore wings: $0.85 \mathrm{~mm}$ (Figure 1b). Antenna with 33 joints, lower face smooth elongate $0.7 \times$ as broad as high, convex with two shallow furrows from median area to upper; presence of small tubercle between base of scapes; head with gena long; posterior ocellus separated from eye by $1.2 \times$ its own maximum diameter. Pronotum long, distance from tegula to head
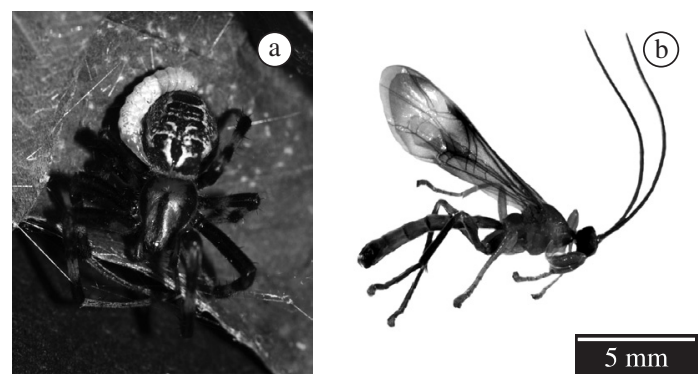

Figure 1. a) Female of $A$. venatrix with larva of $H$. silvanae; b) Habitus of male of $H$. silvanae. is about $0.7 \times$ the distance from tegula to hind margin of propodeum, scutellum convex; mesopleurum smooth and polished with anterodorsal and posteroventral parts with fine and scattered hairs. propodeum smooth and polished with scattered hairs, submetapleural carina absent. Fore wing with cu-a more or less interstitial to base of Rs \& M, vein3r-s absent, hind wing with abscissa of $\mathrm{Cu} 1$ meeting cu-a equidistant between M and 1A. Metasoma moderately slender, tergite I $2.9 \times$ as long as posteriorly margin broad with convergent lateral carinae present only anteriorly, sternite I with slight rounded swelling posteriorly, tergites I-VI centrally smooth and with scattered hairs around, tergite II $1.3 \times$ and tergite III $1.4 \times$ as long as posteriorly broad. Head black, apical margin of clypeus testaceous, mandible except tip, and palpi pale yellow, antenna black. Mesosoma, metasoma and pronotum mostly orange brown, metasoma with tergites II-V with posterior margin darker. Sternite I smooth, orange brown; II - VI light brown and coreaceous. Two pairs of anterior legs yellow, hind leg orange brown with coxa posteriorly, tibia posteriorly and tarsi, tibial spurs brownish. Wings hyaline yellowish; fore wing apically and centrally, between nervelus and junction of radius with stigma with fascia infumate, pterostigma almost all yellow, anteriorly blackish.

Acknowledgements - We were supported financially by the Instituto Nacional de Ciência e Tecnologia dos Hymenoptera Parasitoides da Região Sudeste Brasileira - HYMPAR/Sudeste - CNPq/FAPESP/CAPES), CNPq (Research grants to J.F. Sobczak, A.P.S. Loffredo and A.M. Penteado-Dias). We also thank M. O. Gonzaga for suggestions on the first version of the manuscript. We thank the Prefeitura Municipal de Jundiaí and the staff of the Base de Estudos de Ecologia e Educação Ambiental da Serra do Japi.

\section{References}

EBERHARD, WG., 2000. The natural history and behavior of Hymenoepimecis argyraphaga (Hymenoptera: Ichneumonidae) a parasitoid of Plesiometa argyra (Araneae, Tetragnathidae). Journal of Hymenoptera Research, vol. 9, p. 220-240.

FINCKE, OM., HIGGINS, L. and ROJAS, E., 1990. Parasitism of Nephila clavipes (Araneae, Tetragnathidae) by an ichneumonid (Hymenoptera, Polysphinctini) in Panama. Journal of Arachnology, vol. 18 , p. 321-329.

GAULD, ID., 1991. The Ichneumonidae of Costa Rica, 1. Memoirs of the American Entomological Institute, vol. 47, p. 1-589.

-, 2000. The re-definition of Pimpline genus Hymenoepimecis (Hymenoptera: Ichneumonidae) with a description of a plesiomorphic new Costa Rica species. Journal Hymenoptera Research, vol. 9 , p. 213-219.

GAULD, ID. and DUBOIS, J., 2006. Phylogeny of the Polysphincta group of genera (Hymenoptera: Ichneumonidae; Pimplinae): a taxonomic revision of spider ectoparasitoids. Systematic Entomology, vol. 31, p. 529-564. http://dx.doi.org/10.1111/j.13653113.2006.00334.x

GONZAGA, MO., 2008. Inimigos naturais e defesas contra predação e parasitismo em aranhas. In GONZAGA, MO., SANTOS, AJ. and JAPYASSÚ, HF. Ecologia e Comportamento de aranhas. Rio de Janeiro: Editora Interciência. 
GONZAGA, MO. and SOBCZAK, JF., 2007. Parasitoidinduced mortality of Araneus omnicolor (Araneae, Araneidae) by Hymenoepimecis sp. (Hymenoptera, Ichneumonidae) in Southeastern Brazil. Naturwissenschaften, vol. 94, p. 223-227.

GONZAGA, MO., SOBCZAK, JF., PENTEADO-DIAS., AM. and EBERHARD, WG., 2010. Modification of Nephila clavipes (Araneae: Nephilidae) webs induced by the parasitoids Hymenoepimecis bicolor and $H$. robertsae (Hymenoptera: Ichneumonidae). Ethology Ecology and Evolution, vol. 22, p. 151-165. http://dx.doi. org/10.1080/03949371003707836

LOFFREDO, APS. and PENTEADO-DIAS, AM., 2009. New species of Hymenoepimecis Viereck (Hymenoptera, Ichneumonidae, Pimplinae) from Brazilian Atlantic forest. Revista Brasileira de Entomologia, vol. 53, p. 11-14. http://dx.doi.org/10.1590/S008556262009000100004
SOBCZAK, JF., LOFFREDO., APS, PENTEADO-DIAS., AM. and GONZAGA, MO., 2009. Two new species of Hymenoepimecis (Hymenoptera: Ichneumonidae, Pimplinae) with notes on their spider hosts and behaviour manipulation. Journal Natural History, vol. 43, no. 43-44, p. 2691-2699. http:// dx.doi.org/10.1080/00222930903244010

SOBCZAK, JF., LOFFREDO., APS. and PENTEADO-DIAS, AM., 2011. Description of the male of Hymenoepimecis veranii Loffredo \& Penteado-Dias 2009 (Hymenoptera, Ichneumonidae, Pimplinae). Brazilian Journal of Biology, vol. 71, no. 1. http:// dx.doi.org/10.1590/S1519-69842011000100035

TOWNES, H., 1969. The genera of Ichneumonidae, part 1. Memoirs of the American Entomological Institute, vol. 11, p. 1-300. 
